\title{
SYNTHESIS AND PROPERTIES OF ORGANOSILICON EPISULFIDES
}

\author{
O.V.Askerov, A.F.Mamedova, D.R.Nurullayeva \\ Institute of Polymer Materials, NAS of Azerbaijan \\ aynura.quliyeva79@mail.ru
}

Received 21.06.2021

Accepted 26.08.2021

\begin{abstract}
A study was made of the interaction of thiourea with saturated and unsaturated organosilicon oxiranes in absolute methyl alcohol in a medium of potassium hydroxide, and methods were developed for the synthesis of unsaturated and unsaturated organosilicon silicides with a yield of 65-75\%.The studies carried out revealed that the synthesized organosilicon episulfides are very reactive compounds and can react with nucleophilic and electrophilic reagents, while forming the corresponding silicon derivatives. The IR- spectra of the products were studied. It should be noted that, when comparing the IR- spectra of oxiranes and episulfides, it was revealed that the stretching vibrations of the $\mathrm{CH}_{2}$ group of the episulfide ring are underestimated by $50-70 \mathrm{~cm}^{-1}$ in comparison with the oxirane ring.
\end{abstract}

Keywords: organosilicon episulfides, thiourea, potassium hydroxide, methyl alcohol, organosilicon oxirans.

doi.org/10.32737/0005-2531-2021-4-43-48

\section{Introduction}

The method of the synthesis of saturated and unsaturated organosilicon episulfides by interaction of saturated and unsaturated organosilicon oxiranes with thiourea in a medium of the absolute methyl alcohol in the presence of potassium hydroxide has been developed.

The interest in organosilicon epoxy and episulfide functionally substituted compounds containing functional groups in its composition has been caused not only by their theoretical significance, but also by their practical importance as monomers for obtaining the polymeric materials with valuable operational properties, in particular, frost and petrol resistance on their basis [1-7].

For creation of the thermostable materials suitable for work at higher and lower temperatures, the organosilicon polymeric materials differed by high stability to work at higher temperatures, long aging, stability under conditions of lower humidity are the most perspective [3-6].

Considering the above-mentioned one and in continuation of our investigations [5-7], this work has been devoted to the method of synthesis of $\mathrm{Cl}-, \mathrm{Br}$ - and methoxy-containing organosilicon saturated and unsaturated episulfides by interaction of saturated and unsaturated functionally substituted organosilicon oxiranes with thiourea in a medium of the absolute methyl alcohol in the presence of $\mathrm{KOH}$, leading to the production of functionally substituted organosilicon episulfides, the yield of which is 65$75 \%$, according to the scheme:

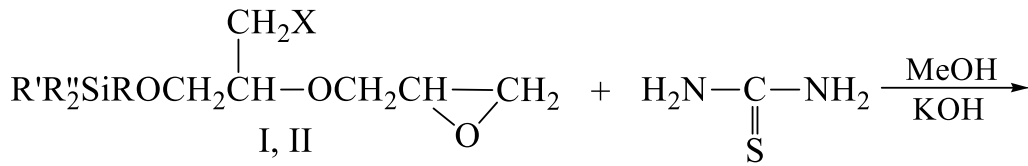

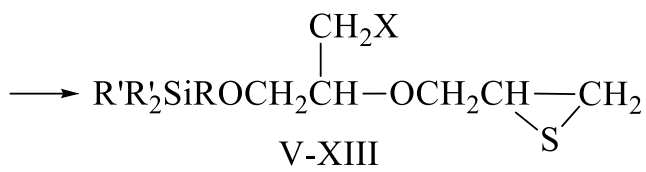

$$
\begin{aligned}
& \mathrm{X}=\mathrm{OCH}_{3}, \mathrm{R}=\mathrm{CH}_{2}-\mathrm{CH}_{2}-\mathrm{CH}_{2}-(\mathrm{I}), \mathrm{R}^{\prime}=\mathrm{R}^{\prime \prime}=\mathrm{C}_{2} \mathrm{H}_{5}(\mathrm{~V}), \\
& \mathrm{R}^{\prime}=\mathrm{CH}_{3}, \mathrm{R}^{\prime \prime}=\mathrm{C}_{2} \mathrm{H}_{5}(\mathrm{VI}), \mathrm{C}_{3} \mathrm{H}_{7}(\mathrm{VII}), \mathrm{C}_{4} \mathrm{H}_{9} \text { (VIII), } \mathrm{C}_{6} \mathrm{H}_{5} \text { (IX) } \\
& \mathrm{X}=\mathrm{Cl}, \mathrm{R}=\mathrm{CH}_{2}-\mathrm{CH}_{2}-\mathrm{CH}_{2}-(\mathrm{II}), \mathrm{R}^{\prime}=\mathrm{CH}_{3}, \mathrm{R}^{\prime \prime}=\mathrm{C}_{2} \mathrm{H}_{5}(\mathrm{X}) \text {, } \\
& \mathrm{C}_{3} \mathrm{H}_{7}(\mathrm{XI}), \mathrm{C}_{4} \mathrm{H}_{9} \text { (XII), } \mathrm{C}_{6} \mathrm{H}_{5} \text { (XIII) . }
\end{aligned}
$$


The composition and structure of the synthesized $\mathrm{Cl}-, \mathrm{Br}-$ and methoxy-containing organosilicon episulfides (V-XXI) have been determined on the basis of their IR and PMR spectra, by chromatographic methods of analysis, as well as by counter synthesis by the interaction of saturated and unsaturated organosilicon alcohols with thioepichlorohydrin in a medium of the absolute methyl alcohol in the presence of $\mathrm{KOH}$, leading to the corresponding episulfides (V-XXI):

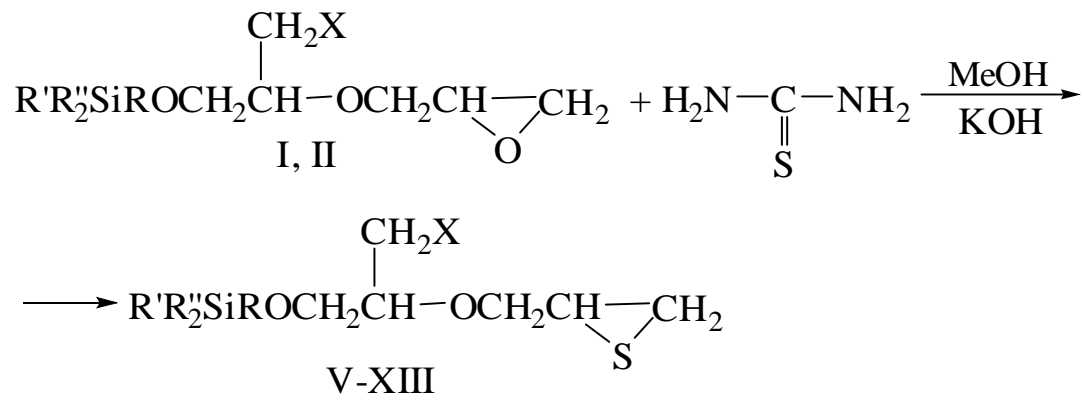

$$
\begin{aligned}
& \mathrm{X}=\mathrm{OCH}_{3}, \mathrm{R}=\mathrm{CH}_{2}-\mathrm{CH}_{2}-\mathrm{CH}_{2}-(\mathrm{I}), \mathrm{R}^{\prime}=\mathrm{R}^{\prime \prime}=\mathrm{C}_{2} \mathrm{H}_{5}(\mathrm{~V}), \\
& \mathrm{R}^{\prime}=\mathrm{CH}_{3}, \mathrm{R}^{\prime \prime}=\mathrm{C}_{2} \mathrm{H}_{5}(\mathrm{VI}), \mathrm{C}_{3} \mathrm{H}_{7}(\mathrm{VII}), \mathrm{C}_{4} \mathrm{H}_{9}(\mathrm{VIII}), \mathrm{C}_{6} \mathrm{H}_{5}(\mathrm{IX}) \\
& \mathrm{X}=\mathrm{Cl}, \mathrm{R}=\mathrm{CH}_{2}-\mathrm{CH}_{2}-\mathrm{CH}_{2}-(\mathrm{II}), \mathrm{R}^{\prime}=\mathrm{CH}_{3}, \mathrm{R}^{\prime \prime}=\mathrm{C}_{2} \mathrm{H}_{5}(\mathrm{X}) \\
& \mathrm{C}_{3} \mathrm{H}_{7}(\mathrm{XI}), \mathrm{C}_{4} \mathrm{H}_{9}(\mathrm{XII}), \mathrm{C}_{6} \mathrm{H}_{5}(\mathrm{XIII})
\end{aligned}
$$<smiles>[X]CC(CO[R16]([R20])=[W])OC1CO1</smiles><smiles>[X]CC(CO[R20]#[R16]C)OCC1CS1</smiles>

$$
\begin{aligned}
& \mathrm{X}=\mathrm{Br}, \mathrm{R}=\mathrm{CH}_{2}=\mathrm{CHCH}_{2}-(\mathrm{III}), \mathrm{R}^{\prime}=\mathrm{CH}_{3}, \mathrm{R}^{\prime \prime}=\mathrm{C}_{2} \mathrm{H}_{5}(\mathrm{XIV}), \\
& \mathrm{C}_{3} \mathrm{H}_{7}(\mathrm{XV}), \mathrm{C}_{4} \mathrm{H}_{9}(\mathrm{XVI}), \mathrm{C}_{6} \mathrm{H}_{5}(\mathrm{XVII}) . \\
& \mathrm{X}=\mathrm{OCH}_{3}, \mathrm{R}=\mathrm{CH}_{2}=\mathrm{CHCH}_{2}-(\mathrm{IV}), \mathrm{R}^{\prime}=\mathrm{CH}_{3}, \mathrm{R}^{\prime \prime}=\mathrm{C}_{2} \mathrm{H}_{5}(\mathrm{XVIII}), \\
& \mathrm{C}_{3} \mathrm{H}_{7}(\mathrm{XIX}), \mathrm{C}_{4} \mathrm{H}_{9}(\mathrm{XX}), \mathrm{C}_{6} \mathrm{H}_{5}(\mathrm{XXI}) .
\end{aligned}
$$

The structure and physical constants of functionally substituted organosilicon episulfides (V-XXI), obtained by both direct and counter synthesis, and were identical.

In the IR spectra of organosilicon episulfides $(\mathrm{V}-\mathrm{XXI})$ there are the absorption bands at $550(\mathrm{C}-\mathrm{Br}), 715(\mathrm{C}-\mathrm{Cl}), 1050(\mathrm{C}-\mathrm{O}-\mathrm{C}), 1615$ $(\mathrm{C}=\mathrm{CH})$ and $3000 \mathrm{~cm}^{-1}$ referring to the indicated groups $[8,9]$. It has been revealed by study of the comparative spectra of oxirane and episulfide that the lowering of the absorption band of episulfide is a consequence of a lower electro-negativity of the sulfur atom in comparison with the oxygen atom.

It has been revealed that the synthesized organosilicon episulfides (V-XXI) are very reactive compounds and can react with electrophilic and nucleophilic reagents. It has been shown that in interaction of organosilicon episulfides with diethylamine it is opened an episulphide ring with the formation of aminomercaptans according to the scheme: 


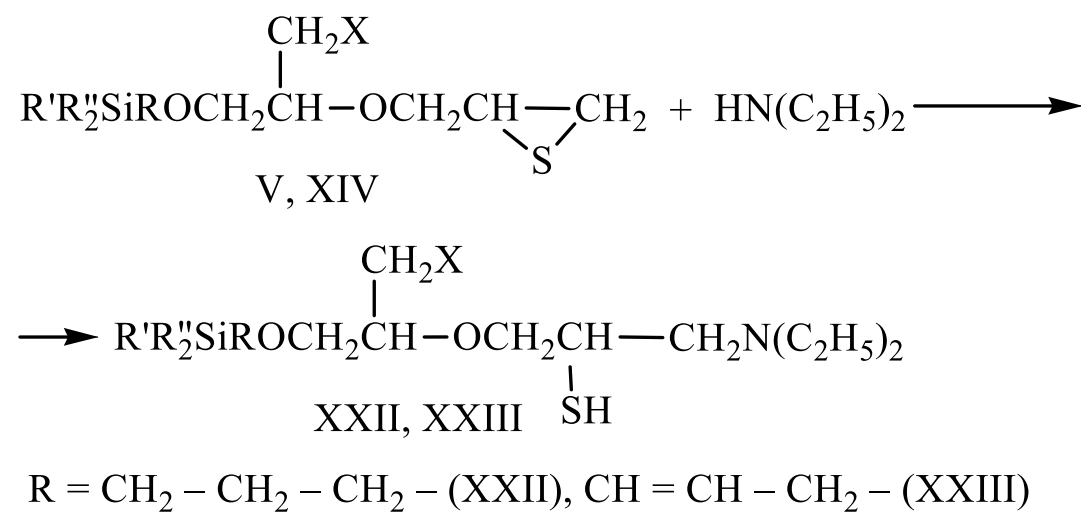

A yield of the compounds (XXII, XXIII) is $75-80 \%$, the structure has been confirmed by IR and PMR spectroscopy.

An absence of the absorption band characteristic for episulfide group in the IR spectra, and an appearance of the bands at $2785(\mathrm{~N}-\mathrm{Et})$ and in the field of $2600-2550 \mathrm{~cm}^{-1}$ characteristic for vibrations of $\mathrm{SH}$-group indicate that the reaction proceeds on episulfide group. It should be noted that in comparison of IR spectra of oxiranes and episulfides (V, XIV), it has been revealed that the valence vibration of the $\mathrm{CH}_{2}-$ group of the episulfide ring has been lowered in comparison with oxirane ring by $50-70 \mathrm{~cm}^{-1}$.

In the PMR spectrum of aminomercaptan (XXII), the signals of the aminomethyl group have been detected as a quartet at $\delta=2.35 \mathrm{ppm}$, and the dimethyl groups of the diethyl radical enter as a singlet at $\delta=1.30 \mathrm{ppm}$.

\section{Experimental part}

The IR spectra of the synthesized compounds were taken on spectrophotometer UR20 in the range of $400-3600 \mathrm{~cm}^{-1}$ in a thin layer.

The PMR spectra were taken on spectrophotometer Tesla BS-487-B $(60,80 \mathrm{MHz})$ in a solution of carbon tetrachloride with internal standard HMDS. The purity of the synthesized compounds was controlled by a method TLC on the plates "Silufol UV-254" in the various systems of solvent and gaseous chromatography on chromatograph LKhM-8MD-5.
Synthesis of organosilicon episulfides. a) $9.7 \mathrm{~g}(0.024 \mathrm{~mol})$ of organosilicon oxirane (I), $27.4 \mathrm{~g}(0.036 \mathrm{~mol})$ of thiourea, $50 \mathrm{~g}$ of absolute methyl alcohol and $\mathrm{KOH}$ are placed in round-bottom flask equipped with mechanical mixer. The content of flask is mixed for $24 \mathrm{~h}$. After usual treatment and distillation of the solvent by vacuum $4.7 \mathrm{~g}$ of episulfide was isolated (V): B.p.145 (0.5 mm merc.c.), $\mathrm{n}_{\mathrm{D}}^{20} 1.4550$, $\mathrm{d}_{4}^{20}$ 0.9444, MR 96.10 (found), 96.51 (calculated). Yield $-58.3 \%$. Found, \%: C 57.76, 57.60; H 10.32, 10.43; S 9.75, 9.66; Si 8.60, 8.44. $\mathrm{C}_{16} \mathrm{H}_{34} \mathrm{O}_{3} \mathrm{SSi}$. Calculated, \%: C 57.44; $\mathrm{H}$ 10.24; $\mathrm{S}$ 9.56; Si 8.39. The IR spectrum of this compound is presented in Figure 1.

There have been obtained the compounds (VI-XXI), physical-chemical constants of which have been presented in Table 1.

b) The reaction mixture consisting of 17.0 $\mathrm{g}(0.12 \mathrm{~mol})$ of episulfide (V), $10.9 \mathrm{~g}(0.15 \mathrm{~mol})$ of diethylamine is stirred at $40^{\circ} \mathrm{C}$ to formation of thick mass. After distillation of the lowboiling components, $22.5 \mathrm{~g}$ of the compound (XXII) was isolated from residue by vacuum distillation. After the second distillation: B.p. $181^{\circ} \mathrm{C}$ (1mm merc.c.), $\mathrm{n}_{\mathrm{D}}^{20} 1.4640, \mathrm{~d}_{4}^{20} 0.8555$. The compound XXIII was obtained similarly with b.p. $192^{\circ} \mathrm{C}$ (1.5 mm merc.c.), $\mathrm{n}_{\mathrm{D}}^{20} 1.4670$, $\mathrm{d}_{4}^{20} 0.9480$. 


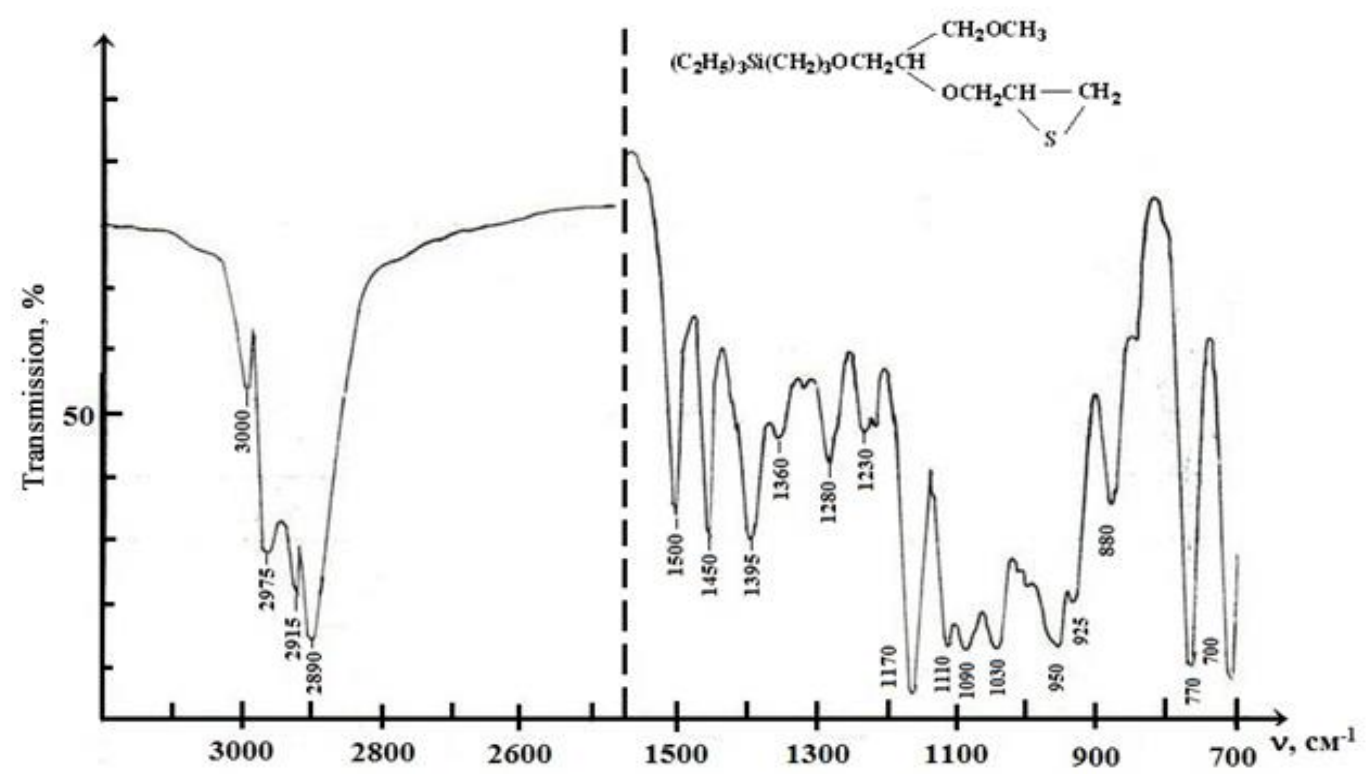

Fig.1. IR spectrum of the compound (V).

Table 1. Physical-chemical characteristics of episulfides

\begin{tabular}{|c|c|c|c|c|c|c|c|}
\hline \multirow{2}{*}{ 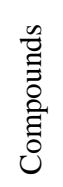 } & \multirow[b]{2}{*}{ Formula of compounds } & \multirow[b]{2}{*}{$\begin{array}{c}\text { Yield, } \\
\%\end{array}$} & \multirow{2}{*}{ 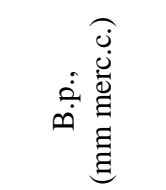 } & \multirow[b]{2}{*}{$\mathrm{n}_{\mathrm{D}}^{20}$} & \multirow[b]{2}{*}{$\mathrm{d}_{4}^{20}$} & \multicolumn{2}{|c|}{$\mathrm{MR}_{\mathrm{D}}$} \\
\hline & & & & & & Found & Calculated \\
\hline VI & $\mathrm{CH}_{3}\left(\mathrm{C}_{2} \mathrm{H}_{5}\right)_{2} \mathrm{Si}\left(\mathrm{CH}_{2}\right)_{3} \mathrm{OCH}_{2}-\mathrm{CHCH}_{\mathrm{OCH}_{2} \mathrm{CH}}^{\mathrm{C}}-\mathrm{CH}_{2} \mathrm{OCH}_{3}$ & 63 & $152(0.3)$ & 1.4530 & 0.9568 & 89.96 & 90.43 \\
\hline VII & $\mathrm{CH}_{3}\left(\mathrm{C}_{3} \mathrm{H}_{7}\right)_{2} \mathrm{Si}\left(\mathrm{CH}_{2}\right)_{3} \mathrm{OCH}_{2}-\mathrm{CH}_{\mathrm{OCH}_{2} \mathrm{CH}}^{-\mathrm{CH}_{2} \mathrm{OCH}_{3}} \stackrel{-\mathrm{CH}_{2}}{\mathrm{~S}}$ & 60 & $158(0.5)$ & 1.4540 & 0.9476 & 95.03 & 95.02 \\
\hline VIII & $\mathrm{CH}_{3}\left(\mathrm{C}_{4} \mathrm{H}_{9}\right)_{2} \mathrm{Si}\left(\mathrm{CH}_{2}\right)_{3} \mathrm{OCH}_{2}-\underbrace{-\mathrm{CH}_{2} \mathrm{OCH}_{3}}_{\mathrm{OCH}_{2} \mathrm{CH}}{ }_{\mathrm{CH}_{2}}^{\mathrm{CH}_{2}}$ & 62 & $165(0.5)$ & 1.4510 & 0.9370 & 103.64 & 104.52 \\
\hline IX & $\mathrm{CH}_{3}\left(\mathrm{C}_{6} \mathrm{H}_{5}\right)_{2} \mathrm{Si}\left(\mathrm{CH}_{2}\right)_{3} \mathrm{OCH}_{2}-\mathrm{CH}_{\mathrm{OCH}_{2} \mathrm{CH}}^{-\mathrm{CH}_{2} \mathrm{OCH}_{3}}-\mathrm{CH}_{2}$ & 65 & $221(0.5)$ & 1.5430 & 1.07017 & 122.66 & 122.70 \\
\hline $\mathrm{X}$ & 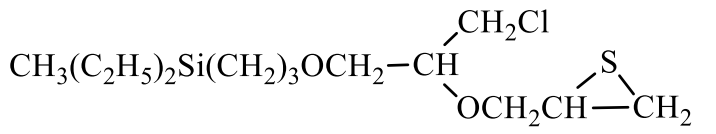 & 66 & $\begin{array}{l}156-157 \\
(0.5)\end{array}$ & 1.4620 & 0.9217 & 91.00 & 90.44 \\
\hline XI & $\mathrm{CH}_{3}\left(\mathrm{C}_{3} \mathrm{H}_{7}\right)_{2} \mathrm{Si}\left(\mathrm{CH}_{2}\right)_{3} \mathrm{OCH}_{2}-\mathrm{CH}_{\mathrm{OCH}_{2} \mathrm{CH}}^{-\mathrm{CH}_{2} \mathrm{Cl}} \stackrel{\mathrm{S}}{\mathrm{S}} \mathrm{CH}_{2}$ & 68.4 & $181(0.5)$ & 1.4630 & 0.9820 & 99.40 & 98.96 \\
\hline XII & $\mathrm{CH}_{3}\left(\mathrm{C}_{4} \mathrm{H}_{9}\right)_{2} \mathrm{Si}\left(\mathrm{CH}_{2}\right)_{3} \mathrm{OCH}_{2}-\mathrm{CH}_{\mathrm{OCH}_{2} \mathrm{CH}}^{-\mathrm{CH}_{2} \mathrm{Cl}} \stackrel{-\mathrm{CH}_{2}}{\mathrm{~S}}$ & 72 & $178(0.5)$ & 1.4650 & 0.9645 & 109.20 & 109.40 \\
\hline XIII & $\mathrm{CH}_{3}\left(\mathrm{C}_{6} \mathrm{H}_{5}\right)_{2} \mathrm{Si}\left(\mathrm{CH}_{2}\right)_{3} \mathrm{OCH}_{2}-\underbrace{-\mathrm{CH}_{2} \mathrm{Cl}}_{\mathrm{OCH}_{2} \mathrm{CH}} \stackrel{\mathrm{CH}_{2}}{\mathrm{~S}}$ & 79 & $221-222(1)$ & 1.5165 & 1.1006 & 121.20 & 121.04 \\
\hline
\end{tabular}




\begin{tabular}{|c|c|c|c|c|c|c|c|}
\hline \multirow{2}{*}{ 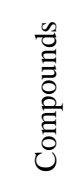 } & \multirow[b]{2}{*}{ Formula of compounds } & \multirow[b]{2}{*}{$\begin{array}{c}\text { Yield, } \\
\%\end{array}$} & \multirow{2}{*}{ 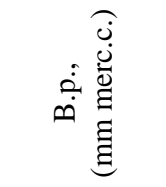 } & \multirow[b]{2}{*}{$\mathrm{n}_{\mathrm{D}}^{20}$} & \multirow[b]{2}{*}{$\mathrm{d}_{4}^{20}$} & \multicolumn{2}{|c|}{$\mathrm{MR}_{\mathrm{D}}$} \\
\hline & & & & & & Found & Calculated \\
\hline XIV & $\mathrm{CH}_{3}\left(\mathrm{C}_{2} \mathrm{H}_{5}\right)_{2} \mathrm{SiCH}=\mathrm{CHCH}_{2} \mathrm{OCH}_{2} \mathrm{CH}$ & 74 & $131.5(0.5)$ & 1.4630 & 0.9756 & 85.40 & 84.75 \\
\hline XV & $\mathrm{CH}_{3}\left(\mathrm{C}_{3} \mathrm{H}_{7}\right)_{2} \mathrm{SiCH}=\mathrm{CHCH}_{2} \mathrm{OCH}_{2} \mathrm{CH}$ & 72 & $141(0.5)$ & 1.4610 & 0.9578 & 94.70 & 94.75 \\
\hline XVI & $\mathrm{CH}_{3}\left(\mathrm{C}_{4} \mathrm{H}_{9}\right)_{2} \mathrm{SiCH}=\mathrm{CHCH}_{2} \mathrm{OCH}_{2} \mathrm{CH}$ & 70 & $158(0.5)$ & 1.4620 & 0.9490 & 103.50 & 104.05 \\
\hline XVII & $\mathrm{CH}_{3}\left(\mathrm{C}_{6} \mathrm{H}_{5}\right)_{2} \mathrm{SiCH}=\mathrm{CHCH}_{2} \mathrm{OCH}_{2} \mathrm{CH}_{\mathrm{OC}}^{\mathrm{CH}}$ & 80 & $201(0.5)$ & 1.5050 & 1.0460 & 95.98 & 95.25 \\
\hline XVIII & $\mathrm{CH}_{3}\left(\mathrm{C}_{2} \mathrm{H}_{5}\right)_{2} \mathrm{SiCH}=\mathrm{CHCH}_{2} \mathrm{OCH}_{2} \mathrm{CH}$ & 79 & 186-187 (1) & 1.5100 & 1.1779 & 92.4 & 92.81 \\
\hline XIX & $\mathrm{CH}_{3}\left(\mathrm{C}_{3} \mathrm{H}_{7}\right)_{2} \mathrm{SiCH}=\mathrm{CHCH}_{2} \mathrm{OCH}_{2} \mathrm{CH}$ & 76 & 191-192 (1) & 1.5160 & 1.1802 & 102.3 & 101.25 \\
\hline$X X$ & $\mathrm{CH}_{3}\left(\mathrm{C}_{4} \mathrm{H}_{9}\right)_{2} \mathrm{SiCH}=\mathrm{CHCH}_{2} \mathrm{OCH}_{2} \mathrm{CH}$ & 78 & $168-169(1)$ & 1.5240 & 1.1658 & 111.41 & 111.00 \\
\hline XXI & $\mathrm{CH}_{3}\left(\mathrm{C}_{6} \mathrm{H}_{5}\right)_{2} \mathrm{SiCH}=\mathrm{CHCH}_{2} \mathrm{OCH}_{2} \mathrm{CH}$ & 80 & 203-204 (1) & 1.5260 & 1.2250 & 114.5 & 114.00 \\
\hline
\end{tabular}

\section{Conclusions}

1. The method of the synthesis of chloro-, bromo-, methoxy-containing saturated and unsaturated episulfides based on the interaction reaction of organosilicon saturated and unsaturated oxiranes with thiocarbamide in a medium of the absolute methyl alcohol in the presence of potassium hydroxide has been developed.

2. It has been shown that chloro-, bromo-, methoxy-containing saturated and unsaturated organosilicon episulphides are very reactive compounds and easily undergo the reaction with electrophilic and nucleophilic reagents, thus forming the corresponding silicon derivatives.

\section{References}

1. Voronkov M.G, Zelchan G.I, Lukevits E.Ya. Silicon and life. Riga: Zinatne, 1978. 588 s.
2. Sobolevsky M.V., Muzovskaya O.A., Popeleva G.S. Properties and applications of silicone products. M.: Chemistry, 1975. 296 p.

3. Borisov S.G., Voronkov M.G., Lukevits E.Ya. Silicone derivatives of phosphorus and sulfur. L.: Chemistry, 1968. P. 298.

4. Petrov A.D., Mironov V.F., Ponomarenko V.A., Sadykh-zade S.I., Chernyshev V.A. Izv. USSR Academy of Sciences, dep. chemical Sciences, 1958, $954 \mathrm{p}$.

5. Askerov O.V., Jafarov V.A., Guliyeva A.F. Khanbabaeva G.D. Halogen-containing heat-resistant composite materials based on silicone dioxides. / Int. scientific and technical conf. "Polymer Composites and Tribology (Polikomtrib-2017)", Gomel, Belarus, 2017. P. 110.

6. Askerov O.V, Jafarov V.A., Guliyeva A.F. Synthesis of Acetate and Silica Oxyoxanes / Materials Int. scientific Conf., dedicated to the 1150th anniversary of the Per-Sid-Tajik encyclopaedist, doc- 
tor, alchemist and philosopher Abu-Bakr Mukhamed ibn Zakariya Razi, Dushanbe, 2016. 145 p.

7. Askerov O.V. Synthesis and some properties of silicone epoxy compounds. Dis.... cand. chem. sciences. Dnepropetrovsk: DGU, 1983. 136 p.
8. Bellamy L. New data on the IR spectra of complex molecules. M.: Mir, 1971. 318 p.

9. Kazitsina L.A., Kupletskaya N.B. The use of UV, IR and NMR spectroscopy in organic chemistry. M.: Higher School, 1971. 264 p.

\section{SILLISIUM ÜZVI EPISULFIDLəRIN SINTEZİ Və XASSəLӘRİ}

\section{O.V.Osgərov, A.F.Məmmədova, D.R.Nurullayeva}

Tədqiqat nəticəsində tiokarbamidlə doymuş və doymamış silisium oksiranların mütləq metil spirti mühitində kalium hidroksidin iştirakı ilə qarşılıqlı təsiri nəticəsində 65-75\% çıxımla doymuş və doymamış silisium üzvi episulfidlərin sintez üsulları işlənib hazırlanmışdır. Aparılan tədqiqatlar nəticəsində aşkar olunmuşdur ki, sintez olunmuş silisium üzvi episulfidlər yüksək reaksiyaya girmə qabiliyyətinə malik olub nukleofil və elektrofil reagentlərlə reaksiyaya girərək müvafiq silisiumlu törəmələrini əmələ gətirirlər. Alınan maddələrin İQ- spektrləri öyrənilmişdir. Bu zaman müəyyən edilmişdir ki, episulfid zəncirinin $\mathrm{CH}_{2}$ qrupunun valent sürüşməsi, oksiran zəncirinin $\mathrm{CH}_{2}$ qrupunun valent sürüşməsindən 50-70 $\mathrm{sm}^{-1}$ aşağıdır.

Açar sözlor: silisium üzvi episulfid, tiokarbamid, kalium hidroksid, metil spirti, silisium üzvi oksiranlar.

\section{СИНТЕЗ И СВОЙСТВА КРЕМНИЙОРГАНИЧЕСКИХ ЭПИСУЛЬФИДОВ}

\section{О.В.Аскеров, А.Ф.Мамедова, Д.Р.Нуруллаева}

Разработан метод синтеза предельных и непредельных кремнийорганических эписульфидов путем взаимодействия тиомочевины с предельными и непредельными кремнийорганическими оксиранами в среде абсолютного метилового спирта в присутствии КОН (выход до 65-75\%). Выявлено, что синтезированные кремнийорганические эписульфиды, являются весьма реакционноспособными соединениями и могут вступать в реакцию с нуклеофильными и электрофильными реагентами, образуя при этом соответствлении производные кремния. Изучены ИК-спектры продуктов. Выявлено что, при сопоставлении ИК-спектров оксиранов и эписульфидов, валентное колебание $\mathrm{CH}_{2}$-группы эписульфидного кольца смещено, по сравнению с оксирановым кольцом, на 50-70 $\mathrm{cm}^{-1}$.

Ключевые слова: кремнийорганические эписульфиды, тиомочевина, гидрооксь калия, метиловый спирт, кремнийорганические оксирань. 